\title{
Monitoring rumen environment in finishing Lidia bulls
}

\section{Monitorización del ambiente ruminal durante la fase de remate del toro de lidia}

\author{
Juan García G,1* Ph.D, Raquel Posado F, ${ }^{1}$ Ph.D, José Zúñiga, ${ }^{2}$ Lic, \\ María Tabernero de Paz R, ${ }^{1}$ Lic, Raúl Bodas R, ${ }^{1}$ Ph.D.
}

\begin{abstract}
${ }^{1}$ Instituto Tecnológico Agrario de Castilla y León - Subdirección de Investigación y Tecnología. Carretera de Carbajosa, s/n, Bajo. 37008 Salamanca. Spain. ${ }^{2}$ Garcisan Distribuciones, S.L. Bernardo Dorado, 2. 37008 Salamanca. Spain.*Correspondencia: gargarjj@itacyl.es
\end{abstract}

Received: September 2015; Accepted: January 2016.

\begin{abstract}
Objective. The aim of this work was to characterize the changes in rumen $\mathrm{pH}$ and temperature in finishing Lidia breed bulls reared on pasture and fed a total mixed ration (TMR). Materials and methods. Five 4-year-old Lidia bulls received approximately $10 \mathrm{~kg}$ of the TMR per animal and day in the morning. Bulls could move freely in a 17-ha fenced area and express normally their feeding behaviour. Internal wireless boluses were used to collect $\mathrm{pH}$ and temperature values every 10 minutes throughout the measurement period. Results. Average daily $\mathrm{pH}$ was 6.2. Average and maximum daily temperatures were not high enough to be indicative of disease (infections of other pathologies). Conclusions. When rations and feeding systems are appropriately managed, Lidia bulls can be supplemented with concentrates in the finishing stages of their productive cycle without impairing the rumen environment.
\end{abstract}

Key words: Acidosis, pH, rations, temperature (Sources: AGROVOC).

\section{RESUMEN}

Objetivo. El presente trabajo pretendió caracterizar las modificaciones que se producen en el pH y la temperatura ruminal de los toros de lidia, criados con un sistema de alimentación basado en el suministro de una mezcla unifeed seca durante la etapa de acabado. Materiales y métodos. Se utilizaron 5 toros cuatreños de la raza de Lidia alimentados con, aproximadamente, $10 \mathrm{~kg} / \mathrm{animal}$ y día de la mezcla unifeed a primera hora de la mañana. Los toros disponían de un espacio cercado de 17 ha, que les permitiría expresar sus patrones de comportamiento de pastoreo en libertad con plena normalidad. El pH y la temperatura ruminal se midió de forma continua utilizando una sonda interna sin cables. Resultados. El pH medio fue de 6.20. Ni los valores de temperatura ruminal medios ni los máximos registrados son excesivamente altos como para ser indicativos del desarrollo de patologías o infecciones que pudieran afectar al estado de los animales. Conclusiones. Mediante el manejo adecuado de las raciones y del sistema de alimentación, puede llevarse a cabo una suplementación con alimentos concentrados para toros de lidia en la fase de remate de manera adecuada y respetuosa con su ambiente ruminal.

Palabras clave: Acidosis, pH, raciones, temperatura (Fuentes: AGROVOC). 


\section{IINTRODUCTION}

Amongst all the breeds of cattle, Lidia bulls are the only ones bred, raised and used with a productive purpose different from meat or milk: behavior.

Over the last decades, traditional extensive production systems of Lidia cattle have gradually been replaced by semi-intensive systems. Thus, the traditional extensive feeding system is followed by a fattening finishing period that usually begins in the summer-autumn of the year before the bullfight. During this finishing period the animals are kept in small fenced areas, where they are fed highly energetic and digestible rations $(1,2)$. This excess of concentrates can cause ruminal acidosis, which has been related to falls during the bullfight, thus severely reducing animal performance $(1,3)$.

Bartolomé (1) reported that $59 \%$ of fighting bulls had rumen $\mathrm{pH}$ values compatible with acidosis, $27 \%$ had liver damage, and $71 \%$ showed rumen paraqueratosis. This author linked liver damage to the animals falling during the bullfight and said that the number of falls was proportional to the severity of liver damage. He also considered that paraqueratosis and low rumen $\mathrm{pH}$ values could negatively influence the animal's behavior while in the bullring.

Rumen temperature is a key factor in conditioning microbial growth, especially when rumen temperature sharply decreases, usually associated to cold water or forage intake (4). The range of physiological rumen temperature $\left(38-42^{\circ} \mathrm{C}\right)$ varies depending on the authors $(5,6)$.

It is, therefore, necessary to deepen the study of this disease and the influence of current feeding systems on bullfight performance with the goal of achieving the required animal volume and fine appearance without compromising rumen function. Thus, the aim of the present work was to study rumen characteristics of finishing bulls fed a total mixed ration.

\section{MATERIALS AND METHODS}

Animals and diets. Five 4-year-old Lidia bulls were used. Animals were handled according to the usual management in their farm, (Tejeda $y$ Segoyuela (Salamanca, Spain; $40^{\circ} 37^{\prime} 56^{\prime \prime} \mathrm{N}$ 6० 01' 21" O; 927 m above sea level, KöppenGeiger's climate classification: Csb), and were fed on a total mixed ration (TMR) whose ingredients and chemical composition are shown in table 1. On average, animals received $10 \mathrm{~kg}$ per day of the TMR, which was supplied early in the morning once a day by means of a feed mixer wagon.

\section{INTRODUCCIÓN}

De todos los bóvidos, la raza de Lidia es la única que se explota con una finalidad productiva diferente a la producción de carne o leche: la producción de comportamiento.

A lo largo de las últimas décadas los sistemas extensivos tradicionales de producción de ganado bravo han sido sustituidos paulatinamente por otros sistemas semi-intensivos. De esta forma, al sistema extensivo tradicional se añade un período de engorde final del ganado, que suele comenzar en el verano-otoño del año anterior a su lidia, en cercados de tamaño reducido y con el suministro diario de raciones de alta concentración energética y digestibilidad $(1,2)$. Este exceso de concentrado puede producir acidosis ruminal, la cual parece estar relacionada con algunos efectos secundarios en forma de caídas durante la lidia, comprometiendo gravemente el rendimiento animal $(1,3)$.

Bartolomé (1) observó que el 59\% de las reses estudiadas se lidiaron con valores de $\mathrm{pH}$ ruminal compatibles con algún tipo de acidosis, 27\% presentaron alguna afección hepática y el $71 \%$ paraqueratosis en la mucosa ruminal. Este autor encontró una relación directa entre la presencia y gravedad de lesiones en el hígado con la aparición de caídas durante la lidia y su relevancia. En lo que se refiere al comportamiento, la presencia de paraqueratosis y un $\mathrm{pH}$ ruminal ácido condicionaron negativamente la respuesta etológica del animal en el ruedo.

La temperatura ruminal condiciona el crecimiento bacteriano en el rumen, sobre todo cuando se producen descensos bruscos de temperatura, asociados a la ingesta de agua o forraje frío (4). Los valores fisiológicos de temperatura ruminal oscilan en un rango entre $38-42^{\circ} \mathrm{C}(5,6)$.

Se hace necesario profundizar en el estudio de esta patología y conocer cómo los actuales sistemas de alimentación de toros de lidia influyen en la misma, para buscar un sistema que permita conseguir el volumen y el trapío exigidos sin alterar la fisiología ruminal, buscando con ello mejorar el rendimiento de los animales durante la lidia. Por consiguiente, el objetivo del presente experimento fue caracterizar las condiciones ruminales de toros criados con un sistema de alimentación basado en el suministro de una mezcla unifeed seca durante la etapa de acabado.

\section{MATERIALES Y MÉTODOS}

Animales y dietas. Se utilizaron 5 toros cuatreños de la raza de Lidia. Los animales 
Table 1. Ingredients and chemical composition of the total mixed ration (TMR).

\begin{tabular}{lc}
\hline Ingredients (g/kg as fed) & \\
\hline Barley straw & 333.3 \\
Corn grain & 213.0 \\
Barley grain & 167.2 \\
Rapeseed meal & 61.9 \\
Beet pulp & 61.9 \\
Cane molasses & 47.6 \\
Maize DDGS & 43.3 \\
Soybean meal & 31.2 \\
By-pass fat ${ }^{1}$ & 12.1 \\
Calcium carbonate & 8.7 \\
Soybean oil & 6.2 \\
Buffer ${ }^{2}$ & 6.2 \\
Vitamin-mineral premix ${ }^{3}$ & 3.1 \\
Calcium phosphate & 2.2 \\
Salt & 2.1 \\
Chemical composition (g/kg dry matter) & \\
\hline Moisture & 96 \\
Crude protein & 108 \\
Crude fibre & 147 \\
Starch & 231 \\
Crude fat & 41 \\
\hline
\end{tabular}

${ }^{1}$ Hepagras J.c., Trow Nutrition, Madrid, Spain. ${ }^{2}$ Biomax (75\% sodium bicarbonate, $25 \%$ magnesium oxide), Trow Nutrition, Madrid, Spain. ${ }^{3}$ Ternimax51 TLIDI, Trow Nutrition, Madrid, Spain.

Animal handling and management was conducted according to Directive 2010/63/EU for the protection of animals used for scientific purposes (7) and, albeit the experimental conditions did not entail animal suffering, the approval certification from the Instituto Tecnológico Agrario de Castilla y León Ethical Committee for Animal Research was gathered. Animals were able to freely and normally move, graze and behave in a fenced space of 17 hectares.

Monitoring of rumen $\mathrm{pH}$ and temperature. Internal wireless smaXtec $\AA$ boluses (smaXtec animal care sales GMBH, Graz, Austria) were used for collecting rumen $\mathrm{pH}$ and temperature data every $10 \mathrm{~min}$. Each bolus ended up in the reticulum (where it remained until the animal was slaughtered) after being calibrated $(\mathrm{pH} 4$ and 7) and introduced using an oral balling gun, following the manufacturer instructions. Data were recorded for a period of 37 ( \pm 8.2 ) days.

Analytical procedures. Procedures described by AOAC (8) were used to determine dry matter (DM, AOAC official method 934.01), ash (AOAC official method 942.05), and Kjeldahl N (AOAC official method 976.06). Neutral-detergent fibre (NDF, expressed including the residual ash) was determined by the method of Van Soest et al (9), adding sodium sulphite to the solution. fueron manejados de acuerdo con los protocolos habituales de la ganadería de origen, situada en el término municipal de Tejeda y Segoyuela (Salamanca, Spain; $40^{\circ} 37^{\prime}$ 56" N 6० 01' 21" 0; $927 \mathrm{~m}$ sobre el nivel del mar, clasificación climática de Köppen-Geiger: Csb), y fueron alimentados con una mezcla unifeed cuyos ingredientes y composición química se detallan en las tabla 1 . Todos los animales recibieron la misma alimentación, aproximadamente $10 \mathrm{~kg} /$ animal y día de la mezcla indicada, suministrada mediante carro unifeed una vez al día, a primera hora de la mañana.

El manejo de los animales se realizó de acuerdo con las condiciones establecidas en la Directiva 2010/63/UE sobre protección de los animales utilizados para fines científicos (7) y, aunque las condiciones experimentales no implicaron un riesgo para los animales, se contó con el aval el Comité de Ética para Experimentación Animal del Instituto Tecnológico Agrario de Castilla y León. Los toros disponían de un espacio cercado de 17 ha, que les permitiría expresar sus patrones de comportamiento de pastoreo en libertad con plena normalidad.

Sondas de pH y temperatura. El pH se midió usando la sonda interna de $\mathrm{pH}$ y temperatura sin cables (SmaXtec animal care sales $\mathrm{GMBH}$, GRAZ, Austria), que tomaba mediciones cada $10 \mathrm{~min}$. Cada sonda fue calibrada usando estándares de $\mathrm{pH} 4$ y 7 antes de ser utilizada. Una vez calibrada, la sonda se introdujo con ayuda de un aplicador vía oral, para ser alojada en el retículo, donde permaneció hasta el sacrificio del animal, momento en que fue recuperada. El periodo de medida que fue de 37 ( \pm 8.2$)$ días.

Procedimientos analíticos. Se utilizaron los procedimientos descritos por la AOAC (8) para la determinación de la materia seca (DM, método oficial 934.01), cenizas (método oficial 942.05) y nitrógeno Kjeldahl (método oficial 976.06). La fibra neutro detergente (NDF, expresada incluyendo la ceniza residual) se determinó siguiendo el método de Van Soest et al (9) añadiendo sulfito sódico a la solución.

La composición química del pienso y de la ración final fue analizada en las dependencias de MasterLab España Analytical Services (Tres Cantos, Madrid).

Análisis de los datos. Los datos de temperatura y $\mathrm{pH}$ obtenidos fueron, en primer lugar, promediados para cada día como máximo, mínimo y medio, área bajo la curva y tiempo en el cual el pH estuvo por debajo de 
The chemical composition and concentrate and mixed ration was analyzed by Master Lab España Analytical Services (Tres Cantos, Madrid, Spain).

Statistical analysis. Data on rumen $\mathrm{pH}$ and temperature were first averaged for each day: maximum, minimum and mean, area under the curve, and time spent below $\mathrm{pH}$ thresholds of 7.0, $6.6,6.2,5.8,5.4$ and 5.0. The area under the curve was calculated by multiplying the absolute value of the deviation in $\mathrm{pH}$ by the time (min) the $\mathrm{pH}$ was below the threshold, and expressed as $\mathrm{pH}$ units $\times$ min. The value of the average $\mathrm{pH}$ for each hour within each day was also calculated for each animal.

Temperature data were summarized as maximum, minimum, and mean and time above 39.0, 39.2, $39.4,39.6$ and $39.8^{\circ} \mathrm{C}$. The area under the curve was calculated as indicated for $\mathrm{pH}$. Temperature data for times of water intake of each animal were identified: the temperature shows a deep decrease followed by a slow increase to near temperature pre-water intake (10). The start of a drinking event was identified when rumen temperature suffered a decline greater than 0.28 ${ }^{\circ} \mathrm{C}$ since the previous measurement. A drinking event ended when temperature was above 38.4 ${ }^{\circ} \mathrm{C}$ or when temperature stopped increasing during a period of $10 \mathrm{~min}$ (10). The correlation analysis between rumen $\mathrm{pH}$ and temperature was performed using SPSS 16.0 for Windows (IBM Corp., New York, USA).

\section{RESULTS}

Descriptive statistics of rumen $\mathrm{pH}$ values are given in table 2. Average rumen $\mathrm{pH}$ was around 6.20 , which can be considered as physiologically normal.

Maximum and minimum values of hours at maximum and minimum $\mathrm{pH}$ seemed to indicate that these $\mathrm{pH}$ values were reached sometimes at specific moments during the night. Nevertheless, quartiles, mode and mean values indicate that minimum $\mathrm{pH}$ was often reached in the afternoon (between 15:00 and 17:00), that is to say, 5 to 8 hours after feed supply. Likewise, maximum $\mathrm{pH}$ value was reached early in the morning (between 8:00 and 10:00). The area under the curve (Time (min/day) $x \mathrm{pH}$ ) for $\mathrm{pH}$ below 5.4 was, on average, $14 \mathrm{~min}$, with a maximum of 30 min for some animals.

Table 3 shows average temperature values of the 5 animals monitored in the experiment. Neither average nor maximum values observed in this experiment were high enough to be related to
$7.0,6.6,6.2,5.8,5.4$ y 5.0. El área bajo la curva se calculó multiplicando el valor absoluto de las desviaciones en el $\mathrm{pH}$ por el tiempo (minutos) que el $\mathrm{pH}$ está bajo el nivel para cada medida.

Para la temperatura se procesaron los datos máximo, mínimo y medio, tiempo por debajo de 38.4 y por encima de 39.0, 39.2, 39.4, 39.6 y $39.8^{\circ} \mathrm{C}$. El área bajo la curva se calculó como se indica para el pH. Los datos de temperatura correspondientes a los momentos de ingestión de agua de cada animal también fueron identificados: la temperatura muestra un descenso inmediato y acusado seguido de un incremento lento hasta alcanzar valores cerca de la temperatura previa a la ingestión de agua (10). Para estos mismos autores el comienzo de un evento de bebida se identificó cuando la temperatura ruminal sufrió un descenso superior a $0.28^{\circ} \mathrm{C}$ desde la medida anterior; y el final del periodo de bebida se consideró cuando la temperatura fue superior a $38.4^{\circ} \mathrm{C}$ o cesó de incrementar sus valores durante un periodo de $10 \mathrm{~min}$ (10). El análisis de correlación entre los valores de $\mathrm{pH}$ ruminal y temperatura se llevó a cabo con el software SPSS 16.0 para Windows (IBM Corp., Nueva York, EUA).

\section{RESULTADOS}

En la tabla 2 se muestran los valores descriptivos de $\mathrm{pH}$ ruminal. El $\mathrm{pH}$ medio se sitúa en torno a 6.20, valor que puede considerarse como fisiológicamente normal.

Los valores máximo y mínimo de las horas a las que se alcanza el $\mathrm{pH}$ máximo y el $\mathrm{pH}$ mínimo parecen señalar que hay momentos puntuales en los cuales los picos extremos de $\mathrm{pH}$ se dan durante la noche. Sin embargo, tanto los cuartiles como la moda y el valor medio son indicativos de que el $\mathrm{pH}$ mínimo suele alcanzarse a primera hora de la tarde (entre las 15:00 y las 17:00), es decir, entre 5 y 8 horas después de haber suministrado la ración. Por su parte, el $\mathrm{pH}$ máximo se alcanza a primera hora de la mañana (entre las 8:00 y las 10:00). El área bajo la curva (Tiempo (min/día) $x \mathrm{pH}$ ) para $\mathrm{pH}$ inferior a 5.40 es, de media, de 14 minutos, si bien en algunos animales alcanza la media hora.

En la tabla 3 aparecen recogidos los valores medios de temperatura de los 5 animales monitorizados. Ni los valores medios ni los máximos registrados fueron excesivamente altos como para indicar el desarrollo de patologías o 
Table 2. Mean values of daily rumen $\mathrm{pH}$ in finishing Lidia bulls.

\begin{tabular}{|c|c|c|c|c|c|c|c|c|}
\hline & Average & Std. dev. & Mode & Min. & Q25 & Median & Q75 & Max. \\
\hline Mean pH & 6.22 & 0.28 & -- & 5.50 & 6.02 & 6.22 & 6.42 & 6.87 \\
\hline Minimum pH & 5.53 & 0.38 & 5.47 & 4.67 & 5.25 & 5.49 & 5.80 & 6.58 \\
\hline Temperature at minimum $\mathrm{pH}$ & 38.46 & w1.97 & 39.56 & 27.72 & 38.25 & 39.03 & 39.71 & 40.77 \\
\hline Hour at minimum pH & $16: 07$ & $7: 31$ & $22: 25$ & $0: 00$ & $14: 07$ & $18: 43$ & $21: 29$ & 23:57 \\
\hline Maximum $\mathrm{pH}$ & 6.80 & 0.21 & 6.97 & 6.11 & 6.64 & 6.82 & 6.97 & 7.30 \\
\hline Temperature at maximum $\mathrm{pH}$ & 38.87 & 0.58 & 38.73 & 33.34 & 38.64 & 38.83 & 39.06 & 40.51 \\
\hline Hour at maximum pH & 9:05 & $2: 53$ & $9: 11$ & $0: 39$ & $7: 48$ & $8: 52$ & $9: 53$ & $22: 26$ \\
\hline \multicolumn{9}{|l|}{ Time ( $\mathrm{min} /$ day) at $\mathrm{pH}<$} \\
\hline 7.0 & 1413 & 129 & 1440 & 150 & 1440 & 1440 & 1440 & 1440 \\
\hline 6.6 & 1090 & 333 & 1440 & 20 & 870 & 1145 & 1400 & 1440 \\
\hline 6.2 & 615 & 382 & 0 & 0 & 310 & 670 & 890 & 1440 \\
\hline 5.8 & 280 & 287 & 0 & 0 & 0 & 210 & 470 & 1110 \\
\hline 5.4 & 77 & 153 & 0 & 0 & 0 & 0 & 80 & 680 \\
\hline 5.0 & 7 & 31 & 0 & 0 & 0 & 0 & 0 & 280 \\
\hline \multicolumn{9}{|l|}{ Time (min/day) $\mathrm{pH}<$} \\
\hline 7.0 & 1115 & 418 & 1489 & 93 & 823 & 1107 & 1403 & 2164 \\
\hline 6.6 & 599 & 362 & -- & 0 & 316 & 578 & 861 & 1588 \\
\hline 6.2 & 258 & 237 & 0 & 0 & 45 & 202 & 402 & 1012 \\
\hline 5.8 & 82 & 117 & 0 & 0 & 0 & 34 & 109 & 566 \\
\hline 5.4 & 15 & 35 & 0 & 0 & 0 & 0 & 6 & 222 \\
\hline 5.0 & 1 & 4 & 0 & 0 & 0 & 0 & 0 & 42 \\
\hline
\end{tabular}

Std. Dev. = standard deviation; Q25 = lower quartile; Q75= upper quartile

Table 3. Average daily values of rumen temperature $\left(T,{ }^{\circ} \mathrm{C}\right)$ in finishing Lidia bulls.

\begin{tabular}{|c|c|c|c|c|c|c|c|c|}
\hline & Average & Std. dev. & Mode & Min. & Q25 & Median & Q75 & Max. \\
\hline Mean T & 38.89 & 0.40 & -- & 37.81 & 38.57 & 38.87 & 39.19 & 39.88 \\
\hline Maximum $\mathrm{T}$ & 40.07 & 0.48 & 39.66 & 39.14 & 39.69 & 40.08 & 40.35 & 42.46 \\
\hline $\mathrm{pH}$ at maximum $\mathrm{T}$ & 5.97 & 0.46 & 5.57 & 4.88 & 5.59 & 6.01 & 6.33 & 6.97 \\
\hline Hour at maximum $\mathrm{T}$ & $15: 56$ & $6: 35$ & $18: 30$ & $0: 03$ & $15: 10$ & $18: 28$ & $20: 02$ & $23: 57$ \\
\hline Minimum T & 32.15 & 2.02 & 33.12 & 27.53 & 30.80 & 32.18 & 33.10 & 39.50 \\
\hline $\mathrm{pH}$ at minimum $\mathrm{T}$ & 6.07 & 0.33 & 6.14 & 5.02 & 5.90 & 6.08 & 6.26 & 6.92 \\
\hline Hour at minimum $\mathrm{T}$ & $14: 03$ & $4: 29$ & $12: 34$ & $1: 05$ & $12: 00$ & $13: 28$ & $16: 18$ & $23: 52$ \\
\hline \multicolumn{9}{|l|}{ Time (min/day) at T > } \\
\hline 39.0 & 730 & 391 & 200 & 50 & 380 & 730 & 1110 & 1370 \\
\hline 39.2 & 563 & 400 & 290 & 0 & 200 & 485 & 920 & 1320 \\
\hline 39.4 & 402 & 364 & 0 & 0 & 80 & 255 & 700 & 1300 \\
\hline 39.6 & 286 & 311 & 0 & 0 & 20 & 150 & 500 & 1230 \\
\hline 39.8 & 183 & 240 & 0 & 0 & 0 & 65 & 300 & 1170 \\
\hline Time (min/day) at $\mathrm{T}<38.4$ & 180 & 85 & 160 & 0 & 130 & 160 & 220 & 540 \\
\hline \multicolumn{9}{|l|}{ Time (min/day) ' $\mathrm{T}>$} \\
\hline 39.0 & 399 & 343 & 105 & 6 & 101 & 294 & 654 & 1460 \\
\hline 39.2 & 269 & 272 & 0 & 0 & 41 & 163 & 462 & 1248 \\
\hline 39.4 & 171 & 203 & 0 & 0 & 15 & 71 & 287 & 1040 \\
\hline 39.6 & 102 & 141 & 0 & 0 & 1 & 31 & 170 & 835 \\
\hline 39.8 & 56 & 91 & 0 & 0 & 0 & 12 & 77 & 634 \\
\hline Time (min/day) ' $\mathrm{T}<38.4$ & 339 & 175 & 0 & 0 & 231 & 326 & 424 & 1390 \\
\hline Average number of water intakes per day & 2.45 & 1.15 & 2.00 & 0.00 & 2.00 & 2.00 & 3.00 & 8.00 \\
\hline
\end{tabular}

Std. Dev. = standard deviation; Q25 = lower quartile; Q75= upper quartile

the development of pathologies or infections that could affect the animals' health. The relative low values of minimum ruminal tempetature (around $32{ }^{\circ} \mathrm{C}$ ) observed could be linked to the moments when the animals drank water. infecciones que pudieran afectar al estado de los animales. Se observaron valores relativamente bajos de temperatura ruminal mínima (en torno a $32^{\circ} \mathrm{C}$ ), lo cual está relacionado con los momentos en los que el animal bebe agua. 


\section{DISCUSSION}

The $\mathrm{pH}$ values observed in this experiment were close to those reported by Bodas et al (11) and above those indicated by other authors $(1,11,12)$ for animals of similar characteristics.

Maximum value of $\mathrm{pH}$ is reached just before feed supply, which agrees with the findings reported by Calsamiglia et al (13) and González et al (14). Feed intake takes place around maximum $\mathrm{pH}$ values, whilst minimum $\mathrm{pH}$ values were the result of the maximum fermentative activity within the rumen after a considerable amount of feed intake. According to Crater et al (15), pH value gradually drops immediately after feed supply and returns to previous values in $24 \mathrm{~h}$, as it can be seen in figures 1 and 2 .

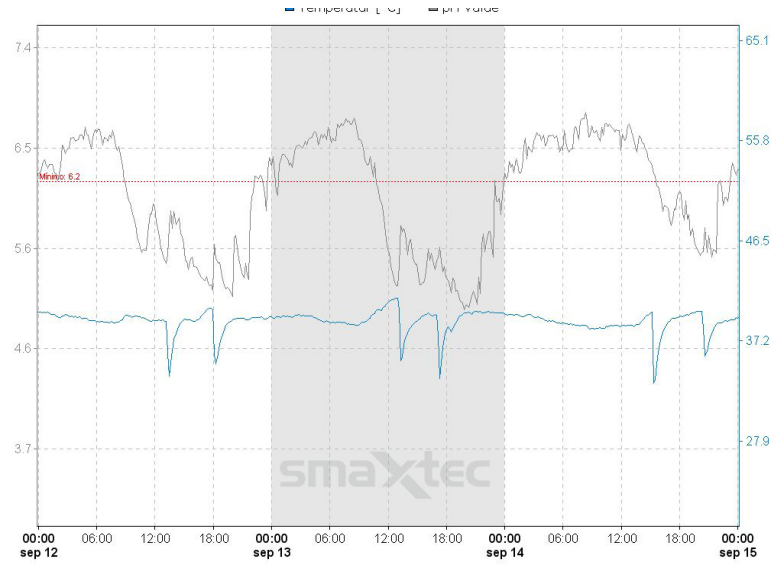

Figure 1. Actual measurements of rumen $\mathrm{pH}$ and temperature for three consecutive days in one Lidia bull fed on a total mixed ration.

The average $\mathrm{pH}$ value observed in this experiment was 6.22 , slightly higher than the 6.08 reported by Bartolomé (1), which can be considered as indicative of chronic acidosis (14). It is well known that when $\mathrm{pH}$ drops beyond this value, fibre digestibility decreases (6). Bartolomé (1) also found evident symptoms of acute ruminal acidosis in all Lidia bulls studied at the end of their productive cycle. This discrepancy between our results and those of former studies could be essentially due to two factors. The first one is related to the way the samples were taken: whereas in our study rumen conditions were continuously monitored, in Bartolomé's (1) study rumen $\mathrm{pH}$ was only measured once the animal had been slaughtered, that is to say, after the animal had suffered acute stress and dehydration. On the other hand, feeding management instead of feed composition (13) is the decisive factor determining rumen $\mathrm{pH}$ and the

\section{DISCUSIÓN}

Los valores de $\mathrm{pH}$ observados estuvieron muy próximos a los indicados por Bodas et al (11) y por encima de los señalados por otros autores para animales de similares características $(1,11,12)$.

El valor máximo de pH máximo se alcanza justo antes del suministro de alimento, coincidiendo con lo publicado por Calsamiglia et al (13) y González et al (14). Así, la ingestión de alimento suele producirse en torno a los valores máximos de $\mathrm{pH}$ (o momentos posteriores), mientras que los valores mínimos de $\mathrm{pH}$ son indicativos del momento en el que se produce la máxima actividad fermentativa en el rumen, tras una ingestión considerable de alimento. En concordancia con lo afirmado por Crater et al (15), el pH del rumen baja de una manera progresiva inmediatamente después del suministro del alimento y retorna a los niveles previos en 24 horas, como puede observarse en las figuras 1 y 2 .

El valor de $\mathrm{pH}$ medio observado en el presente trabajo (6.22) es ligeramente superior a los datos encontrados por Bartolomé (1), cuyo valor medio (6.08) se encuentra dentro del límite considerado como de acidosis crónica (14), y por debajo del cual la digestibilidad de la parte fibrosa de la ración comienza a estar comprometida (6). Bartolomé (1) encontró, además, síntomas evidentes de acidosis ruminal aguda en toros de lidia al final de su ciclo productivo. Esta discrepancia puede deberse, fundamentalmente a dos factores; el primero tiene que ver con el momento de la toma de muestras: mientras que en este trabajo se trató de una monitorización continua de las condiciones ruminales, en el estudio de Bartolomé (1) el pH se midió únicamente tras el sacrificio de los animales, cuando estos habían pasado por una fase de estrés agudo y una deshidratación notable. Por otra parte, como ya se ha señalado (13), el manejo de la alimentación puede resultar más determinante que la composición de la ración o las estrategias nutricionales sobre el $\mathrm{pH}$ ruminal y el consiguiente riesgo de acidosis. Así, aunque el alimento era distribuido para permitir a los animales una ingestión de $10 \mathrm{~kg}$ de mezcla unifeed por cabeza, el sistema de manejo en un cercado amplio (alrededor de 17 ha) les habrá permitido expresar su patrón de comportamiento normal de pastoreo en libertad.

No obstante, es probable que, al disponer de una superficie amplia sobre la que moverse, los animales pasen una gran parte del tiempo alejados del punto donde se suministra la mezcla 

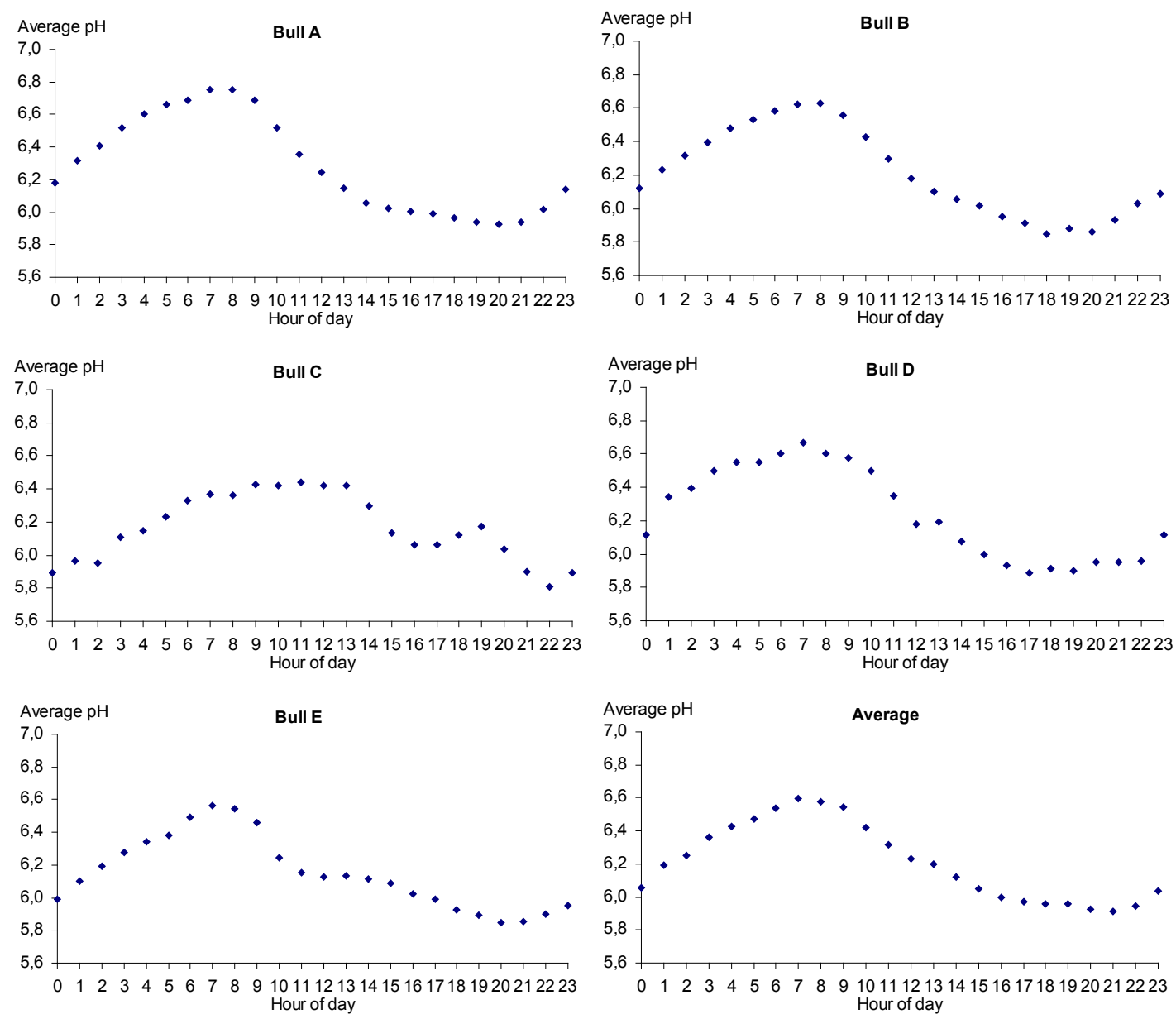

Figure 2. Evolution of rumen $\mathrm{pH}$ throughout the day (average of all the days) for each bull and average of the 5 bulls.

consequent risk of rumen acidosis. Thus, albeit feed was distributed to ensure a minimum TMR intake of $10 \mathrm{~kg}$ per animal, the management system in a fenced area of 17 hectares allowed the animals to graze freely.

Notwithstanding, while the animals graze on a large area, they are likely to spend most of their time away from the spots where TMR is supplied. This circumstance together with the fact that TMR was supplied to the animals in the early morning and remained available in the feeder all day long may contribute to differences in daily feed intake pattern among animals. Hence, when feeds are distributed in punctual moments, even though the space in the feeder is large enough for all the animals, competitive social conditions can lead to competition between individuals, thus reducing the number of meals per day and increasing the amount of feed ingested at each meal, therefore deregulating the mechanisms to maintain optimal unifeed, lo que provocaría que se redujera el número de ingestas y aumentara el volumen de las mismas, con lo cual se dificultaría la regulación del $\mathrm{pH}$ ruminal. Es posible que se den situaciones en las ganaderías en las que, aunque el alimento se distribuya, como en este caso, a primera hora de la mañana y permanezca en el comedero disponible a lo largo del día, puede haber diferencias en el patrón de ingestión de alimento entre animales. Así, la distribución del alimento en momentos puntuales, aún con espacio suficiente en el comedero para todos los animales, da lugar a fenómenos de competencia entre individuos por el acceso al mismo, reduciendo el número de comidas al día e incrementando la cantidad de alimento ingerida en cada comida; esto puede dar lugar a una deficiencia en la regulación de los mecanismos para mantener las condiciones ruminales óptimas $(16,17)$. En este sentido, en nuestro estudio se observó que cada animal mostró un patrón diario (Figura 2) diferente de variación del $\mathrm{pH}$ ruminal, si bien 
rumen conditions $(16,17)$. Each of the monitored animals showed a different daily rumen $\mathrm{pH}$ pattern (Figure 2), and there was no indication either through $\mathrm{pH}$ values or clinical signs that the animals were experiencing acidosis.

The $\mathrm{pH}$ value to ensure an optimum growth of ruminal microorganisms depends on the species of rumen microbiota considered; on average, this value is within the range of 5.5 and 6.9. When $\mathrm{pH}$ values are outside this range, the growth of lactobacilli is favored and acidosis ensues $(5,18)$. The rumen $\mathrm{pH}$ values of the bulls could be considered physiological between 90 and $99 \%$ of the time depending on the animal, thus contributing to a normal ruminal function.

Daily variations in rumen $\mathrm{pH}$ could cause deep modifications in rumen microbiota, so that strong daily variations can be considered worse than a relatively low average rumen $\mathrm{pH}(12,13)$. Our results show that when the average time at $\mathrm{pH}$ under 5.4 are below 15 minutes, changes in ruminal microbiota are not likely to affect rumen physiology. Maintaining a relative low $\mathrm{pH}$ will foster the growth of clostridia and coliform bacteria that will provoke inflammation in the mucosa and the development of hyperkeratosis, thus acting as a barrier for volatile fatty acids absorption $(5,6,19)$.

According to several authors (20-22), temperature is one of the key factors conditioning bacterial growth in the rumen. Rumen temperature is usually 1 or $2^{\circ} \mathrm{C}$ above body temperature (i.e., between 38 and $42{ }^{\circ} \mathrm{C}$ ) due to the number of biochemical processes occurring in the rumen and the homoeothermic regulation of the animal. This temperature can be lowered by the intake of cold water or forage.

It was estimated that there were between 2 and 3 water intakes per day, the main of which took place around 14:00 h., presumably some time after the heaviest TMR intake (that probably took place around 10:00, Figure 2). According to the findings of Wright (23), grazing animals prefer to drink water several times during the day, alternating with feed intake, although water intake frequency highly depends on the relative distance between feed and water areas. Nevertheless, water intake also depends on other factors such as physiological condition, dry matter intake and feed composition, body size, production level, physical activity and environmental factors (e.g. temperature).

In the present study water intake was not related to a drop in ruminal $\mathrm{pH}$ because when temperature reached a value below the physiological level (30.9$\left.33.2^{\circ} \mathrm{C}\right), \mathrm{pH}$ values were within the physiological range $(7,14)$. The amount of time the animals' tanto los datos de $\mathrm{pH}$ como la ausencia de signos clínicos patognomónicos, no permitieron concluir la presencia de procesos de acidosis evidentes.

Cada microorganismo posee un rango de $\mathrm{pH}$ óptimo para desarrollarse $y$, en conjunto, para la microbiota habitual del rumen éste se sitúa entre 5.5 y 6.9; fuera de este rango se favorece el desarrollo de otros microorganismos que alterarían el patrón metabólico del rumen haciendo enfermar al animal $(5,18)$. Así, los individuos monitorizados en este trabajo pasaron dentro del rango fisiológico entre el 90 y el $99 \%$ del tiempo, lo cual evitaría el desarrollo de microorganismos que pudieran alterar la fermentación ruminal.

Variaciones considerables durante el día en los valores de $\mathrm{pH}$ ruminal pueden influir profundamente sobre la población microbiana, de tal forma que son más nocivas las fluctuaciones diarias de $\mathrm{pH}$ que un valor medio relativamente bajo $(12,13)$. Nuestros resultados señalan que tiempos menores de 15 minutos a valores de $\mathrm{pH}$ por debajo de 5.4 no parecen ser suficientes para que se produzcan alteraciones en la microbiota que puedan comprometer la fisiología ruminal. En este sentido, ya se ha señalado que el mantenimiento de un $\mathrm{pH}$ relativamente bajo favorecería el crecimiento de clostridios y coliformes que provocarían una inflamación de la mucosa y el desarrollo de hiper o paraqueratosis, que actuarían como barrera física para la absorción de ácidos grasos volátiles $(5,6,19)$.

La temperatura del rumen es, para diferentes autores (20-22), otro de los factores que condicionan el desarrollo bacteriano. Producto de las reacciones químicas dentro del rumen y de la regulación homeotérmica del rumiante, la temperatura ruminal se mantiene entre 38 y $42^{\circ} \mathrm{C}, 1$ o 2 grados por encima de la temperatura corporal del animal, debido a la enorme cantidad de procesos metabólicos que se producen en él, si bien se pueden lograr descensos de la temperatura ruminal con ingesta de agua o forraje frío.

Tomando como referencia las temperaturas mínimas se ha estimado que la principal ingesta de agua de los animales (de las cuales se producen entre 2 y 3 al día, de media) se sitúa alrededor de las 14:00, posiblemente después de la ingestión más fuerte de alimento (que se podría situar alrededor de las 10:00) (Figura 2). Estas observaciones concuerdan con lo indicado por Wright (23), quien señaló que los animales en pastoreo prefieren consumir agua varias veces al día, alternando con momentos de consumo de alimento, si bien la frecuencia con la que el animal bebe está condicionada por la distancia a la que se encuentra el agua en relación a la zona de alimentación. El consumo de agua, 
rumen presented high temperatures was relatively short: the higher the ruminal temperature, the lower the time spent at that values. Water temperature and water intake, together with the already mentioned factors, may increase the risk of suffering ruminal acidosis (13). Thus, when animals receive a ration that is likely to increase the risk of developing acidosis, drinking water immediately after feed intake will increase acid formation in the rumen (13).

Previous studies show that there is a negative relationship between ruminal $\mathrm{pH}$ and temperature during an acidosis episode, therefore, monitoring ruminal temperature could help to detect such episodes (24). Conversely to this suggestion, in the present study a significant positive relationship between daily average temperature and $\mathrm{pH}$ was observed, although it should be interpreted with caution, given the low value of the correlation coefficient ( $r=0.135 ; p=0.03$; Figure 3$)$.

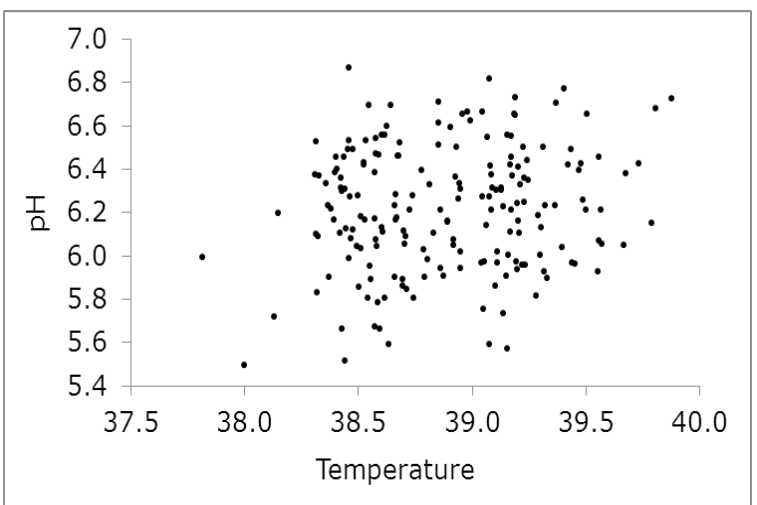

Figure 3. Relationship between daily average temperature and $\mathrm{pH}$ of the 5 bulls $(r=0.153$; $\mathrm{p}=0.03)$.

The results recorded in this work show that average the ruminal $\mathrm{pH}$ in finishing Lidia bulls fed on a TMR was within the range regarded as physiological. As for rumen temperature, neither average nor maximum values were too high to affect the animals. Consequentially, when feeding system is conveniently managed, supplementing finishing Lidia bulls with concentrate rations does not adversely affect the ruminal environment.

\section{Acknowledgements}

Funds received from Garcisan Distribuciones S.L. by means of the project entitled 'Monitorización del ambiente ruminal durante la fase de remate del toro de lidia' (Monitoring ruminal environment in finishing Lidia bulls). además de por estos factores, está condicionado por el estado fisiológico, el nivel productivo, el consumo de materia seca, el tamaño corporal, la actividad física, la composición de la ración, la temperatura ambiente y otros factores ambientales.

En este trabajo no se observó, que la ingestión de agua favoresciera un descenso del $\mathrm{pH}$ a nivel ruminal ya que, como puede verse en la tabla 3, cuando los valores de temperatura ruminal son mínimos (30.94- $\left.33.15^{\circ} \mathrm{C}\right)$, por debajo del rango considerado como fisiológico (7), los valores de $\mathrm{pH}$ se sitúan dentro del rango fisiológico descrito por González et al (14). El tiempo que el rumen pasa a temperaturas altas es relativamente corto: cuanta más alta es la temperatura del rumen menor es el tiempo que el rumen se mantiene en esos valores. La temperatura y el agua consumida, junto a otros factores antes mencionados, pueden influir en la presentación de la acidosis ruminal (13). Así, no es recomendable que los animales que reciban raciones con alto riesgo de inducir acidosis consuman agua durante las primeras horas después de la ingestión de la ración, ya que este comportamiento facilita la producción de ácido a nivel ruminal (13).

Algunos estudios previos indican que existe una relación negativa entre la temperatura y el $\mathrm{pH}$ ruminal durante un episodio de acidosis, por lo tanto, el seguimiento de la temperatura ruminal podría ser de utilidad para detectar tal situación (24). En contraposición con lo sugerido por estos autores, en el presente trabajo se ha observado una correlación positiva entre $\mathrm{pH}$ y temperatura media diaria que, si bien es estadísticamente significativa, debe interpretarse con precaución, dado el bajo valor del coeficiente de correlación $(r=0.153$; $\mathrm{p}=0.03$; Figura 3).

En conclusión, los resultados observados en este trabajo muestran que el $\mathrm{pH}$ ruminal medio en toros de lidia alimentados con mezcla unifeed durante la fase de acabado se sitúa dentro del rango fisiológico. En el caso de la temperatura, ni los valores medios ni los máximos son excesivamente altos como para afectar al estado de los animales. En consecuencia, con el manejo adecuado de las raciones y del sistema de alimentación, puede llevarse a cabo una suplementación con alimentos concentrados para toros de lidia en la fase de remate de manera adecuada y respetuosa con su ambiente ruminal.

\section{Agradecimientos}

Este trabajo ha sido financiado por Garcisan Distribuciones S.L a través del proyecto titulado: "Monitorización del ambiente ruminal durante la fase de remate del toro de lidia". 


\section{REFERENCES}

1. Bartolomé DJ. Influencia de la acidosis ruminal en el síndrome de caída y la respuesta etológica del toro de lidia en la plaza [Tesis Doctoral]. León (Spain): Universidad de León; 2009.

2. Jordán $D$, Villa $N A$, Gutiérrez $M$, Gallego ÁB, Ochoa GA, Ceballos A. Blood chemistry in bullfighting cattle maintained under grazing conditions in Andes Mountains from Colombia. Rev Colomb Ciencias Pecu 2006; 19(1):1826.

3. Lomillos Pérez JM, Alonso de la Varga M, Gaudioso Lacasa V. Análisis de la evolución del manejo en las explotaciones de toro de lidia: desafíos del sector. ITEA-Información Técnica Económica Agraria 2013; 109:49-68.

4. Crater AR, Barboza PS, Forster RJ. Regulation of rumen fermentation during seasonal fluctuations in food intake of muskoxen. Comp Biochem Physiol Part A Mol Integr Physiol 2007; 146(2):233-241.

5. Nagaraja TG, Titgemeyer EC. Ruminal acidosis in beef cattle: the current microbiological and nutritional outlook. J Dairy Sci 2007; 90(Suppl 1):E17-E38.

6. Plaizier JC, Krause DO, Gozho GN, McBride BW. Subacute ruminal acidosis in dairy cows: the physiological causes, incidence and consequences. Vet J 2008; 176(1):21-31.

7. Directiva $2010 / 63 /$ UE del Parlamento Europeo y del Consejo de 22 de septiembre de 2010 relativa a la protección de los animales utilizados para fines científicos. Diario Oficial de la Unión Europea, 20 de octubre de 2010; L276: 33-79.

8. AOAC. Official Methods of Analysis. 19th ed. Gaithersburg, MD: Association of Analitycal Chemists; 2012.

9. Van Soest PJ, Robertson JB, Lewis BA. Methods for dietary fiber, neutral detergent fiber, and nonstarch polysaccharides in relation to animal nutrition. J Dairy Sci 1991; 74(10):3583-3597.
10. Dye TK, Richards CJ. Effect of water consumption on rumen temperature. J Anim Sci. 2008; 86 (Suppl 3): 114.

11. Bodas R, Posado R, Bartolomé DJ, Tabernero de Paz MJ, Herráiz P, Rebollo E, et al. Ruminal $\mathrm{pH}$ and temperature, papilla characteristics, and animal performance of fattening calves fed concentrate or maize silage-based diets. Chil J Agric Res 2014; 74(3):280-285.

12. Moya $D$, Mazzenga $A$, Holtshausen $L$, Cozzi G, González LA, Calsamiglia S, et al. Feeding behavior and ruminal acidosis in beef cattle offered a total mixed ration or dietary components separately. J Anim Sci 2011; 89(2):520-530.

13. Calsamiglia S, Cardozo PW, Ferret A, Bach A. Changes in rumen microbial fermentation are due to a combined effect of type of diet and pH. J Anim Sci 2007; 86(3):702-711.

14. González LA, Manteca X, Calsamiglia S, Schwartzkopf-Genswein KS, Ferret A. Ruminal acidosis in feedlot cattle: Interplay between feed ingredients, rumen function and feeding behavior (a review). Anim Feed Sci Technol 2012; 172(1-2):66-79.

15. Crater AR, Barboza PS. The Rumen in Winter: Cold Shocks in Naturally Feeding Muskoxen (Ovibos moschatus). J Mammal 2007; 8(3):625-631.

16. Schwartzkopf-Genswein KS, Beauchemin KA, McAllister TA, Gibb DJ, Streeter M, Kennedy AD. Effect of feed delivery fluctuations and feeding time on ruminal acidosis, growth performance, and feeding behavior of feedlot cattle. J Anim Sci 2004; 82(11):3357-3365.

17. González LA, Ferret A, Manteca X, Ruíz-dela-Torre JL, Calsamiglia S, Devant M, et al. Performance, behavior, and welfare of Friesian heifers housed in pens with two, four, and eight individuals per concentrate feeding place. J Anim Sci 2008; 86(6):1446-1458. 
18. Brown MS, Ponce $\mathrm{CH}$, Pulikanti R. Adaptation of beef cattle to high-concentrate diets: Performance and ruminal metabolism. J Anim Sci 2006; 84(13 Suppl):E25-E33.

19. Penner GB, Taniguchi M, Guan LL, Beauchemin $K A$, Oba $M$. Effect of dietary forage to concentrate ratio on volatile fatty acid absorption and the expression of genes related to volatile fatty acid absorption and metabolism in ruminal tissue. J Dairy Sci 2009; 92 (6): 2767-2781.

20. AlZahal O, Kebreab E, France J, Froetschel M, McBride BW. Ruminal temperature may aid in the detection of subacute ruminal acidosis. J Dairy Sci 2008; 91(1):202-207.

21. AlZahal O, Rustomo B, Odongo NE, Duffield TF, McBride BW. Technical note: A system for continuous recording of ruminal $\mathrm{pH}$ in cattle. J Anim Sci 2007; 85(1):213-217.
22. AlZahal O, Steele MA, Valdes EV, McBride BW. Technical note: The use of a telemetric system to continuously monitor ruminal temperature and to predict ruminal $\mathrm{pH}$ in cattle. J Dairy Sci 2009; 92(11):5697-5701.

23. Wright CL. Management of water quality for beef cattle. Vet Clin North Am Food Anim Pract 2007; 23(1):91-103.

24. Wahrmund JL, Ronchesel JR, Krehbiel CR, Goad $\mathrm{CL}$, Trost SM, Richards CJ. Ruminal acidosis challenge impact on ruminal temperature in feedlot cattle. J Anim Sci 2012; 90(8):27942801. 